\title{
Povinné předškolní vzdělávání skutečnou součástí školského systému nebo formalitou?
}

\author{
Eva Koželuhová a, Ondřej Koželuh ${ }^{\mathrm{b}}$ \\ ${ }^{a}$ Univerzita Karlova, Pedagogická fakulta, Katedra preprimární a primární pedagogiky \\ b 55. mateřská škola Plzeň
}

Pandemie koronaviru se dotkla všech odvětví lidské činnosti, české školství nevyjímaje. Dne 11. března vydalo Ministerstvo zdravotnictví ČR mimořádné opatření, kvůli kterému došlo k uzavření základních, středních a vysokých škol (MZČR, 2020). To se dotklo i přípravných tříd, které jsou jednou z možností, jak realizovat povinné předškolní vzdělávání. To je u nás převážně naplňováno docházkou do mateřské školy, ty ale nebyly do vládního nařízení zahrnuty, ačkoliv jsou podle $\S 7$ školského zákona 561/2004 Sb. součástí vzdělávací soustavy v ČR a měly by se na ně vztahovat v tomto ohledu stejné podmínky jako na školy vyššího stupně. Ministr školství pouze doporučil „Zvážit omezení nebo přerušení provozu mateřské školy“ (MŠMT, 2020a). Podle $§ 3$ vyhlášky č. 14/2005 Sb., o předškolním vzdělávání, ve znění pozdějších předpisů, tak byla zodpovědnost za zajištění předškolního vzdělávání přenesena na ředitele a zřizovatele mateřských škol. A zatímco ostatní školy přešly na distanční vzdělávání, během něhož měli žáci a studenti povinnost plnit zadávané úkoly, u předškolního vzdělávání se o potřebě plnohodnotně nahradit povinné předškolní vzdělávání nehovořilo vůbec.

\section{Realita povinného předškolního vzdělávání}

Povinné předškolní vzdělávání je u nás zavedeno už třetím rokem, vztahuje se na děti, které dosáhnou do 31. 8. předchozího školního roku pěti let věku, a je realizováno docházkou do mateřské školy, přípravné třídy při základní škole nebo individuálním vzděláváním (zákon 561/2004 Sb). Třebaže impulsem pro zavedení povinné předškolní docházky byla potřeba připravit děti dostatečně na vstup do školy, cíl předškolního vzdělávání je vedením mateřských škol spatřován ve všestranném rozvoji dítěte spíše než v př́ipravě na školní docházku (Simonová, Potužníková, \& Straková, 2017). Toto pojetí je zcela v souladu s Rámcovým vzdělávacím programem pro předškolní vzdělávání. Greger uvádí, že povinná předškolní docházka byla uzákoněna z důvodu, aby všechny děti těžily z př́nosů, které jim tato instituce poskytuje (Greger, Simonová, \& Straková, 2015). Mnohé výzkumy (Belsky et al., 2007; 
Deater-Deckard, Pinkerton, \& Scarr, 1996) navíc prokázaly pozitivní dopady kvalitního předškolního vzdělávání na celý život jedince, z jehož práce pak profituje společnost (podrobněji Průcha, 2016). Zavedení povinného předškolního vzdělávání nemělo jednoznačnou podporu u odborné ani laické veřejnosti (Opravilová, 2016; Simonová et al., 2017). Důvody skepse odborníků spočívaly v náročnosti plošného zavádění (zvýšená administrativa), v nevyjasněném obsahu vzdělávání v posledním roce předškolní docházky a v obavách $\mathrm{z}$ upřednostňování rozvoje funkcí a obsahů, které jsou požadovány při zápisech do škol. Objevovaly se také argumenty, zda je nutné tuto povinnost zavádět plošně, vzhledem k vysoké účasti dětí v předškolním vzdělávání v ČR (Opravilová, 2016). Zavedení povinné předškolní docházky zatím nepřineslo očekávané výsledky, nepodařilo se zapojit děti, na které bylo primárně cíleno (ČŠI, 2018). A situace v době pandemie ukázala, že ač je obecně proklamován význam povinného předškolního vzdělávání, v praxi bylo mimo zájem a pozornost vládnoucích činitelů i MŠMT.

Vedení mateřských škol se v důsledku absence jasných pokynů z MŠMT dostalo do spletité situace, když mělo na jednu stranu povinnost zajistit vzdělávání předškoláků, na straně druhé na ně (a na zřizovatele) byla uvalena plná odpovědnost za uzavření či ponechání chodu mateřských škol. Zároveň se museli ř́́dit usnesením vlády ze dne 15. 3. 2020:

Za ministra školství jsme rozhodli, že vláda nařizuje s účinností od 17 . března 2020 od 6:00 hejtmanům krajů a primátorovi hlavního města Prahy v místech, kde je taková potřeba, určit školu nebo školské zařízení (...) které budou vykonávat nezbytnou péči o děti ve věku od tř́ do deset let (...). Dále vláda nařizuje ministru školství, mládeže a tělovýchovy informovat a metodicky vést kraje a hlavní město Prahu v procesu zajištování vykonávání péče podle bodu 1. (Vláda ČR, 2020b).

Z prohlášení premiéra vyplynulo, že ministr školství k rozhodnutí týkajícímu se jeho resortu nebyl přizván. Vládou ČR mu bylo následně nařízeno „informovat a metodicky vést kraje a hlavní město Prahu v procesu zajištování vykonávání péče“ (Vláda ČR, 2020b). Žádná metodika ani pokyny ze strany MŠMT však vypracovány nebyly. Ředitelé a zřizovatelé tak zůstali na rozhodování sami. Bez jasných pokynů ze strany MŠMT řešili vzniklou situaci různým způsobem. Např́klad v Plzni rozhodli zastupitelé o uzavření všech mateřských škol (Město Plzeň, 2020). Veškerou odpovědnost tedy vzali radní na sebe, přičemž nechali zrrídit dvě mateřské školy, které měly zajistit hlídání dětí osob pracujících u IZS. 
Z nařízení vlády i reakce zřizovatelů je patrné, že v souvislosti s mateřskými školami bylo řešeno pouze zajištění péče o předškolní děti, povinné předškolní vzdělávání nebylo zmiňováno. Ačkoliv nezpochybňujeme uvedená opatření, je zcela zřejmé, že se v této složité situaci dostaly v souvislosti s mateřskými školami do sporu dva odlišné pojmy - hlídání a vzdělávání dětí smísily v jeden. Tím byl potlačen hlavní smysl předškolního vzdělávání, přestože pečovatelská funkce mateřské školy je důležitá a existuje již od jejího vzniku (Opravilová \& Uhliřrová, 2017). Mateřské školy jsou součástí vzdělávacího systému a pracují v nich plně kvalifikovaní učitelé. I ČŠI ve svých závěrech kladně hodnotí, že díky spolupráci mateřských škol a rodičů v době koronaviru mohli rodiče nahlédnout, že „mateřské školy nejsou místem pro hlídání dětí, ale vzdělávací institucí klíčovou pro vývoj a rozvoj dítěte", a doporučuje, aby toto poznání bylo i nadále prohlubováno (ČŠI, 2020, s. 24). Povinné předškolní vzdělávání je přínosné jen za určitých podmínek (blíže Simonová et al., 2017), v každém př́ípadě je ovšem klíčové ono slovo vzdělávání, které se nám v situaci nouzového stavu vytratilo². První reakce MŠMT týkající povinného předškolního vzdělávání přišla až v souvislosti se znovuotevíráním škol, a sice ve znění: „Ani dítě plnící povinné předškolní vzdělávání však nemusí do MŠ nutně do konce školního roku nastoupit, může se se školou domluvit na domácí výuce." (MŠMT, 2020b).

\section{2 Šetření České školní inspekce o průběhu předškolního vzdělávání v době nouzového stavu}

Z výzkumu provedeného Českou školní inspekcí (2020) vyplynulo, že 83 \% uzavřených mateřských škol zajištovalo předškolní vzdělávání v podobě

\footnotetext{
Dokazují to zprávy z různých zdrojů, např jihlavská radnice vydala následující prohlášení: „Usnesení vlády ze dne 16. 3. 2020 uvádí profese rodičů, pro jejichž děti je nutné zajistit hlídání a určit pro tuto službu školu nebo školní zařízení." (Dostupné z https://jihlava. cz/materske-skoly-jsou-v-provozu-pro-deti-rodicu-vybranych-profesi/d-537800/ p1=103430). Kroměřížské zastupitelstvo reagovalo podobně: "Jednu mateřskou školu necháme otevřenou pro rodiče, kteří nemohou zajistit hlídání svého dítěte jinak." (Dostupné z https://www.mesto-kromeriz.cz/aktuality/tiskove-zpravy/mesto-od-ctvrtkazavre-materske-skoly-s-vyjimkou-ms-zizkova/). Starosta městské části Prahy 13 děkoval všem zaměstnancům místních mateřských škol za prázdninový provoz v měsíci červenci: „Je to úžasné rozhodnutí. Určitě pomůže řadě rodičů, kteří každoročně řeší problém se zajištěním prázdninového hlídání dětí. Školy jim tak vyjdou vstříc a pomohou jim s řešením mnohdy komplikované situace. Moc za to děkuji." (Dostupné z https://www.praha13. cz/Materinky-budou-otevrene-i-v-cervenci.html?fbclid=IwAR14brfrGg68VMck-gBqoa qANeLnBse3AlPWMFiK2KhyhXETj3_dl_njqk).
} 
pravidelné nabídky vzdělávacích aktivit, kterou školy zveřejňovaly či přímo zasílaly rodičům dětí. Provedené šetření se týkalo vzdělávání všech dětí docházejících do mateřských škol, nezaměřovalo se explicitně na děti plnící povinnou předškolní docházku. Jeho cílem bylo zjistit, jak mateřské školy v době pandemie fungovaly, a přinést příklady inspirativní praxe. Ty by mohly sloužit jako inspirace, jakými způsoby je možné do budoucna řešit případnou obdobnou situaci. Přestože šetření nebylo zaměřeno na povinnou předškolní docházku, vysoké počty mateřských škol zajištujících distanční předškolní vzdělávání tímto krokem mohly zajistit kontinuitu povinného předškolního vzdělávání a př́ípravy dětí na vstup do základní školy. Zpráva vyzdvihuje kvalitu poskytované péče, kterou v době pandemie většina mateřských škol zajištovala, a zdůrazňuje význam komunikace mezi školou a rodiči. Ukázalo se, že menší mateřské školy (do třiceti dětí) vykazovaly větší míru propojenosti s rodiči a mohly s nimi efektivněji spolupracovat. Dalším pozitivním zjištěním byla vysoká míra zapojení digitálních technologií nejen pro kontakt a komunikaci s rodiči dětí. Na druhou stranu někteří respondenti upozorňovali na problematičnost přenosu vzdělávacího obsahu předškolního vzdělávání distanční formou. Z hlediska zájmu rodičů o plnění povinného předškolního vzdělávání ve zprávě ČŠI nejsou potřebná data. Informuje pouze o tom, že zhruba $30 \%$ rodičů neposkytovalo mateřské škole zpětnou vazbu týkající se průběhu distančního vzdělávání. Z šetření ČŠI také nevyplývá, co vedení mateřských škol motivovalo k zajištění distanční formy předškolního vzdělávání. Bylo by zajímavé a přínosné zjistit, jaké faktory ovlivnily rozhodování vedení mateřských škol a vedly ke snaze alespoň nějakou formou zajistit vzdělávání dětí, jaké cíle byly sledovány a jakou roli v tom hrála snaha zajistit možnost plnění povinného předškolního vzdělávání v posledním roce docházky do mateřských škol. V praxi se nicméně projevilo, že je význam předškolního vzdělávání brán vážně, minimálně pedagogy a vedením škol. Část dotazovaných řídích pracovníků (12\%) reagovala na absenci pokynů ze strany MŠMT a explicitně požadovala lepší podporu a metodické vedení. „Vše jsme řešili naprosto samostatně se souhlasem zřizovatele bez jakékoliv podpory ministerstva školství či jiných institucí, protože všichni směřovali svoji pozornost pouze na základní a střední školství. Směrem k mateřským školám není žádná informovanost, která by ředitelce školy a zřizovateli pomohla v této situaci se dobře orientovat, a rozhodnout tak o znovuotevření škol. Vzdělávání a komunikaci s rodiči jsme taktéž zajistili bez jakékoliv podpory či pomoci." (ČŠI, 2020, s. 23). Toto tvrzení dobře ilustruje, že předškolní 
vzdělávání, a to ani to povinné, nebylo kompetentními orgány dostatečně řešeno. ČŠI ve své zprávě vyzdvihla skutečnost, že mateřské školy plnily svou vzdělávací funkci navzdory obtížné situaci a velice jemně poukázala na selhání zodpovědného orgánu, MŠMT. „Pozitivním zjištěním je velká četnost nabídky rozvojových aktivit ze strany škol, navzdory absenci jakékoli metodické podpory k této činnosti." (ČŠI, 2020, s. 12).

\subsection{Vývoj situace po ukončení karantény}

Během letních měsíců bylo nutné připravit se na nadcházející období spojené s vyšším rizikem výskytu nákazy covid-19. Byly očekávány jasné pokyny a doporučení plynoucí ze zkušeností získaných během karantény. MŠMT počínaje dnem 17. 8. 2020 začalo rozesílat manuály pro fungování škol v novém školním roce (MŠMT, 2020c). Obecné informace, jak postupovat, jsou stejné pro všechny stupně školského systému, přičemž mateřské školy jsou výslovně zmíněny dvakrát (s. 5 a s. 10). Pokyny se týkají převážně hygienických a organizačních opatření, ale nijak neřeší metodickou podporu samotného vzdělávání, at' již z hlediska vzdělávacích cílů, obsahů, metod či forem. Zároveň lze z poslanci schválené novely školského zákona vydedukovat, že mateřské školy do budoucna musí zajištovat $\mathrm{v}$ případě potřeby distanční vzdělávání dětí, kterých se týká povinné předškolní vzdělávání (Vláda ČR, 2020a).

Vzhledem $\mathrm{k}$ cílům předškolního vzdělávání uváděných v RVP PV a věkovým specifikům předškolního období se ovšem dostávají cíle předškolního vzdělávání a distanční výuka do kontradikce. Jakým způsobem se tyto cíle dají distančně naplňovat? Co přesně by měly mateřské školy zajišt’ovat a jak? Mateřské školy již tedy ví, že mají za úkol zajistit v krajním př́ípadě distanční výuku těch dětí, kterých se týká povinné předškolní vzdělávání, ale z hlediska realizace je takto možné de facto splnit pouze jeden z pilírů (rámcových cílů) předškolního vzdělávání, a to rozvoj znalostí a dovedností. Na dálku (především skrze výpočetní techniku) se mezilidské, emoční a sociální kompetence vytvářejí jenom velmi obtížně. Je tedy nasnadě, že distanční vzdělávání v předškolním věku bude především přípravou na školu.

\section{Závěr}

Výše uvedená zjištění naznačují existenci problému, že předškolní vzdělávání je stále v praxi silně vnímáno jako služba zajišt'ující péči o děti pracujících rodičů. Děje se tak i přes mnohá prohlášení o významu předškolního 
vzdělávání a nezměnilo se to ani zavedením povinného posledního roku předškolního vzdělávání. Nouzový stav samozřejmě znamená extrémní podmínky pro každého, ale právě v těch se ukázalo, co je z hlediska státu a zřizovatelů prioritou. Uzákoněním povinnosti účastnit se distančního vzdělávání pro ty děti, kterých se týká povinné předškolní vzdělávání, mělo být signálem, že je mateřská škola chápána jako vzdělávací instituce a že je stejně vážená jako vzdělávání primární a sekundární. Nicméně tento krok je nedostatečně promyšlen, nejsou zohledněny všechny aspekty. Pro mateřské školy vzniká nová povinnost, aniž by jim bylo poskytnuto vedení, jak s ní mají naložit. Do budoucna by proto bylo vhodné:

- Provést hlubší analýzu diskurzu, zahrnující prohlášení vládních činitelů, veřejnoprávních médií a zástupců zřizovatelů v době nouzového stavu, aby bylo osvětleno, jak je v praxi nazíráno předškolní vzdělávání a jeho význam.

- Hledat cesty, jak prohlubovat spolupráci mateřských škol s rodinou, aby v souladu s doporučením ČŠI mohla veřejnost chápat mateřskou školu jako vzdělávací instituci.

- Otevřít odbornou diskuzi o cílech a obsahu předškolního vzdělávání, a to nejen v souvislosti s povinným předškolním vzděláváním. Co chceme, aby předškolní vzdělávání primárně zajišt'ovalo, $\mathrm{k}$ jakým výsledkům má vést, co by mělo být obsahem posledního povinného roku?

Pedagogové prokázali velkou profesionalitu a zodpovědný přístup ke vzdělávání předškolních dětí a nastalá situace může být přínosem a impulzem k dalšímu zlepšování. Koronavirová krize ukázala slabiny a nesystémovost školského systému, kdy se teorie a praxe liší, přičemž je nutné tyto chyby do budoucna eliminovat. Berme to jako prŕležitost.

\section{Literatura}

Belsky, J., Vandell, D., L., Burchinal, M., Clarke-Stewart, K. A., McCartney, K., Owen, M. T., \& NICHD Early Child Care Research Network. (2007). Are there long-term effects of early child care? Child development, 78(2), 681-701.

ČŠI. (2018). Dopady povinného předškolního vzdělávání na organizační a personální zajištění a výchovně-vzdělávací činnost mateřských škol za období 1. pololetí školního roku 2017/2018.

Tematická zpráva. Dostupné z https://www.csicr.cz/getattachment/494adcd7-2e4b40a7-b564-383d964ce14d/TZ-Dopady-povinneho-predskolniho-vzdelavani.pdf

ČŠI. (2020). Vzdělávánív mateřských školách v době nouzového stavu. Tematická zpráva. Dostupné z https://www.csicr.cz/Csicr/media/Prilohy/PDF_el__publikace/Tematick\%c3\%a9\%20 
zpr\%c3\%a1vy/Vzdelavani-v-materskych-skolach-v-obdobi-nouzoveho-stavu-Tematickazprava.pdf

Deater-Deckard, K., Pinkerton, R., \& Scarr, S. (1996). Child care quality and children's behavioral adjustment: A four-year longitudinal study. Journal of Child Psychology and Psychiatry, 37(8), 937-948.

Greger, D., Simonová, J., \& Straková, J. (Eds.). (2015). Spravedlivý start? Nerovné šance v předškolním vzdělávání a při přechodu na základní školu. Praha: Univerzita Karlova, Pedagogická fakulta.

Město Plzeň. (2020, 11. března). Plzeň uzavře od čtvrtka 12. března mateřské školy na svém území [Tisková zpráva]. Dostupné z https://www.plzen.eu/o-meste/aktuality/aktuality-zmesta/plzen-uzavre-od-ctvrtka-12-brezna-materske-skoly-na-svem-uzemi.aspx

MZČR. (2020). Mimořádné opatření - uzavření základních, středních a vysokých škol od 11. 3. 2020. Dostupné z http://www.mzcr.cz/dokumenty/mimoradne-opatreni-uzavrenizakladnichstrednich-a-vysokych-skol-od-11320_18696_4135_1.html

MŠMT. (2020a). Informace $k$ vyhlášení nouzového stavu v ČR. Dostupné z https://www.msmt.cz/ informace-k-vyhlaseni-nouzoveho-stavu-v-cr?highlightWords=uzavření\% $20 \mathrm{mš} \& \mathrm{fbclid}=\mathrm{I}$ wAR3HNot8d4MNpFPQ5J8KmVfWmsOt3NkSWX-Key6iqQd4DLhoOmR3r_FxP9c

MŠMT. (2020b). Nejčastější dotazy k aktuálním opatřením ke koronaviru. Dostupné z https:// www.msmt.cz/faq-nejcastejsi-dotazy-k-aktualnim-opatrenim-ke-koronaviru

MŠMT. (2020c). Provoz škol a školských zařízení ve školním roce 2020/21 vzhledem ke covid-19. Dostupné z https://www.msmt.cz/manual-k-provozu-skol-od zari?fbclid=IwAR2RvcC_ InK1DLUpMWK3OFBbHzEv_w_SGLnungSxEUKhftZ5guAK6yJiK3c

Opravilová, E. (2016). Předškolní pedagogika. Praha: Grada.

Opravilová, E., \& Uhlířová, J. (2017). Příběhy české mateřské školy: vývoj a proměny předškolní výchovy. Praha: Univerzita Karlova, Pedagogická fakulta.

Průcha, J. (2016). Předškolní dítě a svět vzdělávání: přehled teorie, praxe a výzkumných poznatků. Wolters Kluwer.

Simonová, J., Potužníková, E., \& Straková, J. (2017). Poslání a aktuální problémy předškolního vzdělávání - postoje a názory ředitelek mateřských škol. Orbis Scholae, 11(1), 71-91.

Vláda ČR (2020a). Návrh zákona, kterým se mění zákon č. 561/2004 Sb., o předškolním, základním, středním, vyšším odborném a jiném vzdělávání (školský zákon), ve znění pozdějších předpisů. Dostupné z https://apps.odok.cz/djv-agenda?date=2020-08-17

Vláda ČR (2020b). Tisková konference po mimořádném jednání vlády 15. 3. 2020. Dostupné $\mathrm{z}$ https://www.vlada.cz/cz/media-centrum/tiskove-konference/tiskova-konference-pomimoradnem-jednani-vlady-15--brezna-2020-180361/

Zákon 561/2004 Sb.

\section{Autoři}

Mgr. Eva Koželuhová, Univerzita Karlova, Pedagogická fakulta, Katedra preprimární a primární pedagogiky, M. Rettigové 4, 11301 Praha 1, e-mail: eva.kozeluhova@pedf.cuni.cz

Mgr. Ondřej Koželuh, 55. mateřská škola Plzeň, Mandlova 6, 30100 Plzeň, e-mail: coroner@volny.cz 